„Studia Wyborcze”, tom 32, 2021

DOI: https://doi.org/10.26485/SW/2021/32/4

\title{
Marta Czakowska*
}

iD https://orcid.org/0000-0002-5839-9267

\section{O GWARANCJACH REALIZACJI SWOBÓD WYNIKAJACYCH Z ZASADY WOLNYCH WYBORÓW W SYSTEMIE PRAWNYM U PROGU XX-LECIA MIĘDZYWOJENNEGO}

\section{UWAGI WPROWADZAJĄCE}

W państwach, w których przyjęto ustrój demokratyczny, organizacja i przeprowadzenie wyborów ma niezwykle doniosły charakter. Wydarzenie tej rangi ma znaczenie nie tylko polityczne, ale jako akt ,,autentycznej partycypacji wyborczej" w ewoluującym społeczeństwie obywatelskim stanowi źródło i nieocenioną wartość demokracji dla jego członków [Grabowska, Szawiel 2003: 13-14]. Nie sposób nie zgodzić się z Arkadiuszem Żukowskiem, w którego ocenie demokracja jest urzeczywistniona wówczas, gdy „rządzący gotowi są oddać władzę w rezultacie wyborów" [Żukowski 2004: 5] oraz kiedy ich wyłanianie nastąpi w tejże formie.

Mimo że wolne wybory uznawane są za ,synonim demokracji” [Sokala 2010: 24], to trudno w rzeczywistości wskazać na istotę tej zasady, choć w doktrynie światowej takie próby trwają od lat. Przedstawiciele doktryny prawa nie mają wątpliwości, iż zasadę wolnych wyborów należy rozpatrywać i wiązać z zasadą pluralizmu politycznego czy wręcz ,wyidealizowanego postulatu" przyjętego na potrzeby kolejnych procesów wyborczych [Kryszeń 2008: 178]. Wolność stoi w opozycji do przymusu, zatem, podając za Andrzejem Antoszewskim [2006: 194], wolne wybory wolne pozbawione są ograniczeń

* Dr, adiunkt, Instytut Nauk Prawnych, Wydział Nauk Prawnych, Społecznych i Humanistycznych, Kujawsko-Pomorska Szkoła Wyższa w Bydgoszczy, radca prawny przy Okręgowej Izbie Radców Prawnych w Bydgoszczy, m.czakowska@kpsw.edu.pl 
nakładanych na wyborców lub na konkurentów występujących w rywalizacji wyborczej [Antoszewski 2006: 178]. Każdorazowo dokonywana ocena stopnia demokratyzmu przeprowadzanych wyborów odbywa się według kryterium wolności wyborów [Kryszeń 2008: 178].

Zdaniem Leszka Garlickiego [2010: 153] zasadę wolnych wyborów należy rozpatrywać łącznie z zasadą pluralizmu politycznego, a oznacza ona tyle, co „Zagwarantowanie swobodnego udziału podmiotów politycznych w wyborach”.

Z kolei Jan Galster [2002: 170] wyraża pogląd, iż wolność wyborów „polega na nieskrępowanym wyrażaniu preferencji wyborczych", co w istocie nie sprowadza się do wolności od głosowania, ale stanowi o wolności wyboru.

Zdaniem Marka Chmaja [2008: 36] realizacja zasady wolnych wyborów polega na możności korzystania przez każdego uprawnionego z należnego mu prawa wyborczego z wyłączeniem przymusu w każdej postaci lub jakiejkolwiek formy przymusu.

W ocenie Stanisława Bożyka [2006: 42] wybory wolne to w pełni demokratyczne, przeprowadzone według zasady pluralizmu politycznego oraz „możliwości swobodnego wyboru określonej orientacji i programu politycznego, [...] mających za zadanie realizację podstawowych założeń tego programu".

Znaczenie zasady wolnych wyborów podkreśla także Bogusław Banaszak, poprzez wskazanie, iż jej celem jest zagwarantowanie swobodnej realizacji aktu wyborczego, przejawiającej się możnością korzystania przez wyborców z przysługujących im praw bez jakichkolwiek form przymusu, eliminacją każdej postaci angażowania się w proces wyborczy, wykluczeniem wszelkich form monopolu politycznego oraz zapewnieniem nieskrępowanej możliwości zgłaszania kandydatów, przy jednoczesnym zapewnieniu warunków do prowadzenia kampanii wyborczej [Banaszak 2008: 364; 1993: 3-4].

Z weryfikacji poglądów polskich konstytucjonalistów dokonanej przez Jerzego Buczkowskiego wynika, że zasada wolności wyborów rozumiana jest niekiedy jako „«Wolna gra» sił politycznych i występowanie pluralizmu partyjnego" bądź też jako brak aktywności organów państwa w procesie wyborczym, występowanie bez ograniczeń konkurencyjności kandydatów, możność prowadzenia pozbawionej ograniczeń politycznych kampanii wyborczej, zapewnienie „dobrze poinformowanym" wyborcom szeroko pojętej możliwości podejmowania decyzji ${ }^{1}$ wyborczych, niestosowanie przymusu wyborczego, zapewnienie gwarancji swobody wyrażania woli poprzez tajność głosowania [Buczkowski 1998: 219]. Natomiast Stanisław Gebethner [1989: 4] wskazał, że na nieostre pojęcie wolnych wyborów składają się trzy elementy - rywalizacji kandydatów i programów, „swobody

\footnotetext{
${ }^{1}$ Jerzy Buczkowski podaje za innymi autorami przymiotnik ,,rozsądnych”; wydaje się, iż ma to wymiar subiektywny, na pograniczu emocjonalnego, stąd decyzja o jego niestosowaniu [M. Cz.].
} 
wyrażania przez wyborców ich woli w nie skrępowanym i wolnym od nacisku władz akcie głosowania", a także uczciwe przeprowadzenie całej procedury wyborczej, w tym rzetelne ustalenie wyników głosowania.

W konkluzji wskazać należy za Grzegorzem Kryszeniem [2008: 90], iż zasadę wolnych wyborów determinują trzy wolności: wyłaniania i zgłaszania kandydatów (list kandydatów), prowadzenia kampanii wyborczej oraz swobody preferencji wyborczych.

Pogląd ten, uzupełniony przez Andrzeja Sokalę o konieczność jednoczesnego przestrzeganiu dyrektywy uczciwości procesu wyborczego [Sokala 2010: 60], w pełni odzwierciedla przekonanie, iż wolne wybory są synonimem demokracji.

Dziś, podobnie jednak jak na początku ubiegłego wieku, rozumienie tych fundamentalnych zasad prawa wyborczego, nie zawsze było spójne. Interpretacja ich zależała niejednokrotnie od wielu czynników - społecznych, kulturowych, ale przede wszystkim politycznych. Podkreślenia jednak wymaga okoliczność, iż obecny stan prawny oraz podejmowane działania faktyczne mające znamiona dobrej praktyki wyborczej, ugruntowane zostały na podstawie wielu istotnych dla współczesnego państwa prawa, jakim jest Rzeczpospolita Polska, faktów oraz regulacji prawnych mających miejsce w latach 1918-1989. Przyjęcie tej cezury czasowej ma szczególne uzasadnienie. Odrodzenie wolnego państwa polskiego w 1918 roku stanowiło początek wielu istotnych dla historii państwa i prawa polskiego wydarzeń. Wiele oczekiwanych przez społeczeństwo zmian społecznych i gospodarczych zapoczątkowanych $\mathrm{w}$ dwudziestoleciu międzywojennym nie znalazło swej kontynuacji w okresie powojennym.

\section{SWOBODA ZGŁASZANIA KANDYDATÓW U PROGU XX-LECIA MIĘDZYWOJENNEGO}

Za jedno z najważniejszych wydarzeń $\mathrm{w}$ dziejach państwa polskiego uznać należy narodziny niepodległej Rzeczypospolitej. Celem powołanej na mocy aktu 5 listopada z 1916 roku przez generalnych gubernatorów Tymczasowej Rady Stanu (TRS) było stworzenie podstaw państwowości w Królestwie Polskim [Ilski 2013: 421]. Do priorytetów działalności powołanej przez TRS Komisji Konstytucyjnej należało stworzenie przez dwie podkomisje - konstytucyjną i sejmową - odpowiednio projektów ustawy zasadniczej, prócz części dotyczącej pozycji sejmu, oraz ordynacji wyborczej wraz z uzupełnieniem przepisów dotyczących sejmu [Ilski 2013: 421; Kacperski 2007: 28; Siemieński 1918; Buzek 1918; Jodko-Narkiewicz 1918]. Wówczas państw z ugruntowanym system demokratycznym nie było zbyt wiele, jednak w literaturze podawano przykłady rozwiązań, w zakresie tego elementu procesu wyborczego, 
które można dziś uznać za innowacyjne. Feliks Ochimowski [1906: 88-89] wskazał na regulacje obowiązujące choćby w Finlandii, gdzie wyborcy w liczbie co najmniej 50 mogą ,stworzyć Koło (stowarzyszenie) wyborcze, w formie specyalnego aktu z pełnomocnikiem na czele". Takiemu kołu ustawodawca przyznawał prawo do zgłoszenia wyłącznie listy z trzema kandydatami. Zaś co najmniej dwa koła wyborcze miały możność utworzenia związku wyborczego, który w danym okręgu wyborczym nie mógł wspólnie zgłosić więcej kandydatów, niż przewiduje się mandatów do uzyskania [Ochimowski 1906: 88-89].

\section{INSTYTUCJA PEŁONOMCNIKA}

Za jedną ze wspólnych cech czynności podejmowanych w procesie wyborczym w ówczesnych państwach europejskich, bez względu na fakt stosowania różnego rodzaju cenzusów, F. Ochimowski [1906: 92] uznał działania podejmowane przez ,agentów stronnictw, zgromadzenia i komitety przedwyborcze" ${ }^{\text {" }}$. W literaturze podkreślano istotę etapu procesu wyborczego polegającego na „ogłaszaniu przez partie swych kandydatów” [X 1906]. Z pewnością wzorce stosowane w innych państwach stały się fundamentem prac ciał legislacyjnych powołanych na potrzeby stworzenia podstaw ustroju tworzonego w niedalekiej przyszłości państwa polskiego.

Spośród kilku przygotowanych projektów ordynacji wyborczych [Ilski 2013: 422] $]^{3}$ podstawę prac stanowił projekt Józefa Buzka oraz Józefa Siemieńskiego. W zakresie zasad zgłaszania kandydatów w wyborach do sejmu, J. Buzek przyjął konwencję zgłaszania kandydatów na ręce przewodniczącego głównej komisji wyborczej w danym okręgu przez grupe 50 członków, jeśli lista zarejestrowana miała być w kilku miejskich okręgach - przez 100 członków, przy czym dopuszczalne było kartelowanie, czyli łączenie kilku list w jedną [Buzek 1918] $]^{4}$. W dalszej kolejności J. Buzek wskazał regułę usytuowania na liście kandydatów według preferowanego pierwszeństwa przez „grupe”, jednak celem udaremnienia „samowoli komitetów wyborczych”, wyborca dokonywał wyboru poprzez podkreślenie nazwiska wybranego przez siebie kandydata na liście, tym samym tworząc gradację preferencji przed pozostałymi kandydatami [Buzek 1918].

${ }^{2}$ Autor podaje także rodzaje komitetów przedwyborczych, wśród których wyróżnia centralne i miejscowe. Powoływano je w celu nie tylko usprawnienie procesu wyborczego, ale także po to, by „ułatwić zwycięstwo stronnictwu (partyi), frakcyi lub fakcyi”.

${ }^{3}$ Projekty ordynacji wyborczych zostały przedstawione - do Sejmu przez J. Siemieńskiego, S. Kutrzebę, J. Buzka, do Senatu - przez Z. Cybichowskiego.

${ }^{4}$ Autor stosuje sformułowanie „członków”, wydaje się jednak, iż intencja tego sformułowania dotyczy członków danej społeczności, zatem wyborców na danym terenie. 
Natomiast J. Siemieński [1918: 13] przyjął w projekcie swego autorstwa konstrukcję „obywatelskich komitetów wyborczych”, tworzonych przez grupę co najmniej 50 wyborców posiadających czynne prawo wyborcze w danym okręgu, których zadaniem było zgłoszenie list kandydatów w urzędowym biurze wyborczym. Autor wprowadził także, powszechnie dziś znaną i stosowaną, instytucję wyrażenia zgody na kandydowanie. Tylko nazwiska tych kandydatów, którzy złożyli oświadczenie woli o treści pozytywnej, mogły znaleźć się na liście komitetu wyborczego. Warunkowo także mogło być umieszczone nazwisko kandydata, który takiej woli nie wyraził, jeżeli fakt złożenia przez niego takiego oświadczenia w innej formie, został potwierdzony przez co najmniej pięciu członków komitetu [Siemieński 1918: 13].

Urzędowe biuro wyborcze, zgodnie z założeniami projektu J. Siemieńskiego [1918: 13], zobowiązane było przyjąć zgłoszenie takiego kandydata z jednoczesnym zastrzeżeniem, iż członkowie komitetu, w terminie już uzgodnionym przez komisję sejmową, dostarczyliby wymagane oświadczenie. Idea zgłoszona przez J. Siemieńskiego dotyczyła także silnej identyfikacji obywatelskich komitetów wyborczych w toku prowadzonej rywalizacji wyborczej, co polegało na obowiązku zgłoszenia także barw wyborczych w stopniu dostatecznie odróżniającym dany komitet od pozostałych ${ }^{5}$.

W opozycji do tych projektów stały te przygotowane przez Biuro Pracy Społecznej (BPS), które było związane ze środowiskiem ugrupowań lewicowych. Prace nad projektami ordynacji wyborczej w jego ramach prowadzili Tadeusz Jankowski, Mieczysław Niedziałkowski, Tadeusz Hołówko, Włodzimierz Wakar i Antoni Bogusławski [Ilski 2013: 436-437]. Wypracowano jeden wspólny projekt ordynacji wyborczej przez Komisję Administracyjną Biura, faktycznie dotyczący tylko obszaru Królestwa Polskiego. Jednym z odzwierciedlonych tam założeń Komisji było przyznanie prawa zgłaszania kandydatów na posłów przez grupę wyborców liczącą co najmniej 100 osób. Autorzy projektu dopuszczali także możliwość łączenia się grup w związki wyborcze. Ponadto przyjęto także możność kandydowania w więcej niż jednym okręgu wyborczym [Ilski 2013: 436-437].

W przededniu restytucji państwa polskiego rozpoczęły się prace nad ordynacją wyborczą do konstytuanty skupione wokół Rady Regencyjnej. Podłożem tych prac był projekt uprzednio opracowany w ramach Komisji Konstytucyjnej TRS przez J. Siemieńskiego i J. Buzka, a ich efektem było przedłożenie Radzie Regencyjnej niejako uproszczonej jego wersji zatytułowanej Projekt dekretu o ordynacji wyborczej do sejmu [Ilski 2013: 441].

\footnotetext{
${ }^{5}$ Decyzję w zakresie dostatecznego odróżniania się zgłoszonych barw komitetu, w szczególności od już zarejestrowanych barw innych komitetów, podejmowało urzędowe biuro wyborcze.
} 
Z kolei powołany rząd Józefa Świeżyńskiego rozpoczął własne prace nad projektem ordynacji wyborczej, których podstawę stanowił projekt Komisji Administracyjnej BPS, w ramach zespołu, w skład którego wchodzili Mieczysław Niedziałkowski, Zygmunt Chrzanowski i Włodziemierz Wakar. Jednak rząd ten został po blisko 10 dniach zdymisjonowany. Na czele nowego rządu stanął Jędrzej Moraczewski, który podjął się zobowiązania do przygotowania projektu ordynacji wyborczej do sejmu ustawodawczego w terminie $10 \mathrm{dni}$ [Ilski 2013: 441]. Zespół w składzie Mieczysław Niedziałkowski, Stanisław Thugutt, Józef Buzek przygotował projekt ordynacji wyborczej stanowiącej kompilację rozwiązań przyjętych przez zespół Z. Chrzanowskiego oraz Komisję Administracyjną BPS [Ilski 2013: 441]. Kluczowym zadaniem władz odrodzonego w 1918 roku państwa polskiego, było przyjęcie zasad w określonych ramach prawnych, na których podstawie zostaną zorganizowane i przeprowadzone wybory.

Dekret Naczelnika Państwa z 28 listopada 1918 roku o ordynacji wyborczej do Sejmu Ustawodawczego ${ }^{6}$ określił zasady procesu wyborczego dla tegoż organu. Zgodnie z przepisami rozdziału IV „Wybory poselskie” podrozdziału d) „Zgłaszanie kandydatur poselskich” warunkiem zgodnego z prawem zgłoszenia kandydata było złożenie w formie pisemnej kandydatury na ręce przewodniczącego głównej komisji wyborczej nie później niż na 24 dni od dnia ogłoszenia wyborów (art. 43). Zgłoszenie to uznane był za złożone zgodnie z przepisami prawa, jeśli kandydatowi udzieliło poparcia co najmniej 50 wyborców zamieszkujących dany okręgu wyborczy (art. 44). Antoni Bogucki [1918: 11] wskazał, iż zgłoszenie kandydatur poselskich nie wymagało zastosowania określonego wzoru formularza, a mogło mieć miejsce na zwykłym arkuszu papieru. Dopuszczalne było także złożenie podpisów popierających daną kandydaturę na odrębnych arkuszach papieru, pod warunkiem spełnienia wymogu uzyskania łącznie 50 podpisów wyborców deklarujących poparcie dla kandydata. Arkusze te stanowiły jedno zgłoszenie.

Wnioskować zatem należy, iż uprawnienie to przysługiwało wyłącznie grupie wyborców. Jednak w rzeczywistości uprawnienie to realizowały ugrupowania polityczne [Kacperski 2007: 94] za pośrednictwem swoich członków i zwolenników [Ajnenkiel 1991: 212]. Warto dodać, iż działalność tych ugrupowań po odrodzeniu państwa polskiego nie została prawnie uregulowana.

Zasada swobodnego powstawania i działalności partii politycznych nie znalazła wówczas oparcia w procedurze ich legalizacji [Chmaj, Żmigrodzki 1995: $33]^{7}$. Przepisy ordynacji nie obligowały podmiotów zgłaszających kandydatów,

\footnotetext{
${ }^{6}$ Dz. U. P. P. P. nr 18, poz. 46.

${ }^{7}$ Autorzy wskazują ponadto, iż dopiero tuż przed wyborami do Sejmu Ustawodawczego na mocy postanowień dekretu z dnia 3.01.1919 r. o stowarzyszeniach (Dz. U. P. P. P. nr 3, poz. 255)
} 
by podpisy pod zgłoszeniem były poświadczone przez stosowne organy, dysponujące uprawnieniem poświadczania faktów i zdarzeń prawnych [Kacperski 2007: 94]. Brak regulacji w tym zakresie podaje zatem w wątpliwość rzetelność i uczciwość całej procedury.

W toku prac nad ordynacją z 1918 roku podnoszono konieczność zwiększenia liczby podpisów pod zgłoszeniem danej kandydatury, co zdaniem wnioskodawców stanowiłoby niejako próg selekcji dla niewielkich ugrupowań politycznych, a w konsekwencji mogłoby zapobiec rozdrobnieniu sił politycznych w Sejmie [Kacperski 2007: 94]. Zgłoszone listy kandydatów, zgodnie z postanowieniami art. 45 ordynacji z 1918 roku, oznaczane były przez główną komisję wyborczą w kolejności ich składania, zaś nadany numer stanowił jednocześnie oznaczenie numeryczne listy kandydatów.

\section{INSTYTUCJA PEŁNOMOCNIKA W WYBORACH}

Celem usystematyzowania procesu komunikacji z organami wyborczymi, grupa zgłaszająca kandydata, została zobligowana do wyznaczenia pełnomocnika, który zgodnie z treścią art. 46 ordynacji z 1918 roku, składał oświadczenia woli w sprawie ewentualnych wad dokonanego zgłoszenia. Innym uprawnieniem pełnomocników była możliwość złożenia nie później niż do 27. dnia od dnia ogłoszenia wyborów oświadczenia o utworzeniu z innymi grupami związków wyborczych, które traktowane były jako jedna grupa w stosunku do pozostałych grup wyborczych. A. Bogucki podkreślał, iż złożenie oświadczenia o utworzeniu związku wyborczego mógł dokonać tylko i wyłącznie pełnomocnik grup wchodzących w skład tego związku, wyraźnie do tej czynności upoważniony [Bogucki 1918: 11]. Komentarz ten stwarza domniemanie zastosowania instytucji pełnomocnictwa do poszczególnych czynności. W treści dekretu o ordynacji wyborczej z 1918 roku charakter samego pełnomocnictwa nie jest jednoznacznie określony. Brak w nim sformułowania o dokonywaniu wszelkich czynności w imieniu danego kandydata czy też związku wyborczego. Zatem nie jest wykluczona konieczność legitymowania się takim upoważnieniem do dokonywania kolejnych czynności w toku procesu wyborczego przez pełnomocnika. Zgłoszenia związków wyborczych stanowić miały jedno zgłoszenie (art. 47). Intencją dla tak przyjętego rozwiązania nie było stworzenie koalicji, która wystawiałaby jedną listę [Kacperski 2007: 95]. Każda z tych

partie polityczne, do których odnoszono się jak do stowarzyszeń, zostały wezwane do dokonania rejestracji. Procedury rejestracji dokonywał Minister Spraw Wewnętrznych. 
grup (stronnictw) mogła wystawić własną listę. Tym samym element konkurencyjności pozostawał nadal realizowany w ramach jednego związku wyborczego. Ich zgłoszenia traktowane były jako pojedyncze (art. 47).

Kwestią, która nie została rozstrzygnięta w przepisach ordynacji wyborczej z 1918 roku, był problem możności zgłaszania liczby kandydatów w stosunku do liczby mandatów. Unormowania w tym zakresie z pewnością przyczyniłyby się do usprawnienia procesu wyborczego, poprzez zapobieżenie sytuacji nieobsadzenia mandatów w danym okręgu z uwagi na niewielką liczbę kandydatów, tj. mniejszą niż przewidziana liczba mandatów. Z kolei zbyt wysoka liczba kandydatów w stosunku do liczby mandatów, mogłaby stanowić przyczynek do rozdrobnienia politycznego, zjawiska niepożądanego w obliczu odradzającej się państwowości. Jako argument za koniecznością uregulowania kwestii liczby zgłaszanych kandydatów J. Siemieński [1919: 40] wskazał udaremnienie lub niwelowanie nadużyć wyborczych przez choćby zgłaszanie dużej liczby kandydatów, wśród której byłyby także jednostki nierespektowane powszechnie przez wyborców. Ten rodzaj manipulacji wyborcą J. Siemieński [1919: 42-43] uznał za niedopuszczalną niegodziwość wobec wyborców. W mojej ocenie postępowanie takie stanowiło naruszenie zasady zaufania obywatela do państwa, nawet jeśli ta zasada wówczas nie była explicite wyrażona w aktach normatywnych. Zgłoszenia kandydatów opatrzone powinny być następującymi danymi: imionami, nazwiskami, informacją o zawodzie, wieku i miejscu zamieszkania kandydata (art. 49), zaś kandydaci w zgłoszeniu powinni być wymienieni w porządku pierwszeństwa, w jakim wybrani wchodzą do sejmu (art. 48). Twórcy ordynacji wyborczej z 1918 roku nie zastosowali jednej z nadrzędnych dla nauk prawnych teorii oświadczeń woli. Nie było zatem wymagane przepisami prawa złożenie oświadczenia woli o kandydowaniu. Wnioskować należy, iż kandydat mógł być zgłoszony wbrew własnej woli, co godzi w podstawowe prawa i wolności polityczne [Kacperski 2007: 96].

J. Siemieński [1919: 42], poddając to krytyce wskazał, iż brak zgody na kandydowanie może wywołać skutek w postaci chronicznego, a nawet patologicznego wystawiania kandydatów reprezentujących odmienne poglądy polityczne tylko i wyłącznie po to, aby w przypadku nieuzyskania mandatu przez rodzimego kandydata przez niefrasobliwość wyborców mógł ten mandat uzyskać. Ten sam kandydat mógł korzystać z biernego prawa wyborczego w wielu okręgach wyborczych (art. 50) [Brzoza 1989: 562-563] . $^{8}$

\footnotetext{
${ }^{8}$ Krytykę tak przyjętego rozwiązania podniósł na łamach „Głosu Narodu” S. Kutrzeba, określając je mianem ,absurdalnego", ponieważ w kilkudziesięciu miejscach w Polsce będą popularne nazwiska, jak Paderewski, Piłsudski, co stanie się przyczyną ,zamętu pojęciowego" i dezorientacji wśród wyborców.
} 
Zastosowanie instrumentu wejścia kolejnego kandydata $\mathrm{z}$ listy w przypadku zrzeczenia się mandatu $\mathrm{w}$ danym okręgu przez posła pierwotnie wybranego, skutkowało niejako wprowadzaniem w błąd wyborców. Wyborcy bowiem byli dotąd przeświadczeni o preferencji konkretnego kandydata i tym samym, pozostając w niewiedzy ${ }^{9}$ o korzystaniu przez nich z biernego prawa wyborczego $\mathrm{w}$ innym okręgu, dokonywali wyboru wbrew własnym przekonaniom [Siemieński 1919: 43]. Na mocy przepisu art. 51, pełnomocnikowi grupy została przypisana kompetencja zadośćuczynienia wezwaniu do uzupełnienia braków formalnych poczynionym w 28. dniu od dnia ogłoszenia wyborów przez główna komisję wyborczą, pod rygorem stwierdzenia nieważności całego zgłoszenia kandydatów bądź konkretnego kandydata (art. 51, 52). Wybór posłów mógł, na mocy postanowień art. 53 i 54, odbyć się w tradycyjnej drodze głosowania bądź ogłoszenia przez główną komisję wyborczą o wyborze kandydatów na posłów. Sytuacja ta miała miejsce wówczas, gdy liczba kandydatów była mniejsza niż liczba mandatów w danym okręgu wyborczym. Mając na względzie dopuszczalność kandydowania jednocześnie w więcej niż jednym okręgu wyborczym i tym samym ewentualność wielokrotnego wyboru na posła, od wybranego posła wymagano złożenia oświadczenia najpóźniej na pierwszym posiedzeniu sejmu o wyborze okręgu, z którego mandat uzyskał [Bogucki 1918: 23]. Wystąpienie okoliczności polegającej na wyborze tego samego kandydata na posła w więcej niż jednym okręgu wyborczym, skutkowało także zastosowaniem procedury wygaśnięcia mandatu w tym niewskazanym przez niego okręgu wyborczym i możność wejścia kandydata z listy, który uzyskał kolejny rezultat wyborczy [Bogucki 1918: 22].

Na początku 1919 roku rząd Jędrzeja Moraczewskiego powołał Biuro Konstytucyjne. Wynikiem jego prac było sporządzenie trzech projektów ustawy zasadniczej. Działania te nie spotkały się z przychylnością Sejmu. Alternatywę dla prac rządu w tym zakresie stanowiła powołana dnia 14 lutego 1919 roku Komisja Konstytucyjna pod przewodnictwem Władysława Seydy [Ajnenkiel 1991: 227]. Ideą łączącą podjęte prace nad kolejnymi projektami konstytucji, także przez inne stronnictwa parlamentarne, było stworzenie stabilnej, republikańskiej formy państwa [Ajnenkiel 1991: 229]. Natomiast zagadnieniem wzbudzającym największe kontrowersje podczas debat konstytucyjnych była problematyka dwuizbowości parlamentu [Momro 2013: 21]. Spory polityczne na tle kolejnych wizji konstytucji ustały wraz z ofensywą wojsk radzieckich w 1920 roku. Pozytywne dla strony polskiej zakończenie tego konfliktu, a także włączenie Śląska do Rzeczpospolitej, spowodowały przyspieszenie prac parlamentarnych nad projektem konstytucji. Debata publiczna nad podstawowymi

\footnotetext{
${ }^{9}$ Wynika to $\mathrm{z}$ faktu braku obowiązku informowania na afiszach w danym okręgi informacji o kandydowaniu danej osoby także w innym okręgu wyborczym.
} 
kwestiami politycznymi i społecznymi, które miały znaleźć odzwierciedlenie w konstytucji, przybrała niespotykaną na tak szeroką skalę formę edukacji obywatelskiej [Ajnenkiel 1991: 237].

Ta narodowa lekcja demokracji w szczególności znalazła wydźwięk w przepisach rozdziału uchwalonej 17 marca 1921 roku ustawy zasadniczej, zapisanej na kartach historii jako „konstytucja marcowa”, które dotyczyły zasad sejmowej ordynacji wyborczej. Prace nad nową ordynacją wyborczą do sejmu rozpoczęto dopiero po uchwaleniu konstytucji marcowej. Przyczyną takiego stanu rzeczy było powstanie jeszcze większego rozdrobnienia politycznego $\mathrm{w}$ parlamencie jako konsekwencja gorliwych dyskusji i polemik w toku prac nad kolejnymi projektami konstytucji. Trwające ponad rok prace parlamentarne zakończyły się uchwaleniem w dniu 28 lipca 1922 roku ordynacji wyborczej do Sejmu ${ }^{10}$. W przepisach art. 44 do 61 został ustanowiony tryb zgłaszania kandydatów, który powielał niektóre z rozwiązań normatywnych przyjętych w ordynacji z 1918 roku. Warunkiem zgłoszenia kandydatury w danym okręgu wyborczym było złożenie $\mathrm{w}$ formie pisemnej zgłoszenia przewodniczącemu okręgowej komisji wyborczej w terminie do 30. dnia przed wyborami.

Rozwiązaniem legislacyjnym dotąd nie mającym odzwierciedlenia w przepisach prawa było wprowadzenie obowiązku dostarczenia nie później niż do 22 . dnia przez wyborami do rąk przewodniczącego okręgowej komisji wyborczej oświadczenia woli kandydata złożonego w formie pisemnej, opatrzonego własnoręcznym podpisem, o zgodzie na kandydowanie. Ponadto ustawodawca wskazał na obowiązek zawarcia w treści tego oświadczenia stwierdzenia, iż kandydat uważa się za obywatela polskiego oraz posiada, „wedle swej najlepszej wiedzy", bierne prawo wyborcze. Brak oświadczenia o tej treści skutkował wykreśleniem kandydata z listy przez okręgową komisję wyborczą. Rozwiązanie przyjęte w tym zakresie pod względem formalno-prawnym budziło wiele wątpliwości. Nie sposób nie zgodzić się z Wacławem Komarnickim [1932: 32-33], iż „subiektywne przekonania jednostki [...] jest bez znaczenia prawnego” w odniesieniu do oświadczenia woli o przynależności państwowej i posiadanym biernym prawie wyborczym.

Kandydat mógł być zgłoszony wyłącznie na jednej liście wyborczej (art. 44 ust. 3). Zdaniem J. Buzka [1922: 74] była to próba „obejścia” niepożądanych zachowań wyborczych, bowiem kandydaci mogli być zgłoszeni także w innym okręgu wyborczym, co w przypadku liderów lub innych znanych społeczeństwu

${ }^{10}$ Dz. U. R. P. nr 66, poz. 590. 
osobistości z pewnością było stosowane ${ }^{11}$. Zgłoszenie, zgodnie z art. 45, miało być podpisane przez co najmniej 50. wyborców zamieszkałych w danym okręgu wyborczym [Buzek 1922: 70] $]^{12}$.

Jednak podpisy poparcia danej kandydatury nie wymagały ich uwierzytelnienia, choćby przez określoną grupę obywateli. Konsekwencją takiego stanu rzeczy mogło być zaistnienie nieprawidłowości polegających na składaniu podpisów za osoby fikcyjne lub zmarłe. Każde stwarzanie pola do nadużyć przez ustawodawcę podważa ideę uczciwego procesu wyborczego [Komarnicki 1922: 60]. Ustawodawca dopuszczał możliwość złożenia tych oświadczeń łącznie, bądź na odrębnych formularzach. Na uwagę zasługuje także przyjęcie rozwiązania, które nie zostało unormowane w ordynacji z 1918 roku, polegającego na możności zgłoszenia w okręgu wyborczym liczby kandydatów stanowiącej nie więcej niż dwukrotność liczby mandatów przypadających w danym okręgu. Mając na względzie nieścisłości w tym zakresie w przepisach ordynacji z 1918 roku przyjąć wypada, iż było to dobre rozwiązanie.

Ustawodawca posiadający $\mathrm{w}$ dużej mierze doświadczenia $\mathrm{w}$ stosowaniu przepisów uprzedniej ordynacji wyborczej do Sejmu, poczynił wiele starań, aby zapobiec sytuacji nie obsadzenia mandatów, bądź z drugiej strony rozdrobnieniu politycznemu zagrażającemu stabilizującemu się państwu. Wskazanie wraz z pisemnym zgłoszeniem kandydatów osoby pełnomocnika, a także jego zastępcy, do porozumiewania się z władzami wyborczymi oraz składania oświadczeń w sprawie zgłoszenia, stanowiło wówczas wyraz dobrej praktyki w sprawach wyborczych (art. 48 ust. 1 i 2). Cofnięcie pełnomocnictwa, wzorem rozwiązań przyjętych w prawie cywilnym, zarówno wobec pełnomocnika, jak i jego zastępcy, uznane było za skuteczne, jeśli składający oświadczenie woli o odwołaniu opatrzą je czytelnymi podpisami, wraz z podaniem swojego wieku, zawodu i dokładnego adresu, w sposób i w formie nie budzącej wątpliwości. Oświadczenia takie będą ważne, jeśli zostaną potwierdzone przez przełożonego gminy, bądź przewodniczącego obwodowej komisji wyborczej (art. 48 ust. 3). Pełnomocnik pochodzący z nowego mianowania, pełni rolę ustępującego pełnomocnika, pod warunkiem stwierdzenia przez obwodową komisję wyborczą, iż odwołanie nastąpiło zgodnie z przepisami ordynacji wyborczej. Obowiązek podpisu zgłoszenia okręgowej listy kandydatów, wraz z podaniem wieku, zawodu,

${ }^{11}$ Autor wskazuje przykład Czechosłowacji, Belgii i Francji, gdzie jest zakaz kandydowania w więcej niż jednym okręgu.

${ }^{12} \mathrm{~J}$. Buzek podaje, iż w tym czasie w Austrii konieczne było poparcie listy kandydatów składanej w okręgu wyborczym przez 100 wyborców, zaś poparcie dla listy państwowej winni wyrazić pełnomocnicy z cn. pięciu list zgłoszonych w okręgach wyborczych przez dane stronnictwo; w Rzeszy Niemieckiej wymagano poparcia listy kandydatów przez cn. 50 wyborców, z kolei listy państwowej jedynie przez 20 wyborców; w świetle postanowień ordynacji czesko-słowackiej wymagane jest poparcie listy okręgowej kandydatów przez 100 wyborców, z tym że jest wymóg uwierzytelnienia tych podpisów przez notariusza, sąd lub starostwo. 
dokładnego miejsca zamieszkania ciążył na wyborcach na podstawie przepisu art. 48. Podobnie w przypadku zgłoszonych list kandydatów, w których nazwiska powinny były być oznaczone kolejnymi numerami, poczynając od numeru 1., w porządku pierwszeństwa do otrzymania mandatu (art. 51).

Po raz pierwszy w historii polskiego prawa ustawodawca w przepisie art. 49 wskazał na konieczność oznaczenia listy kandydatów poprzez określenie stronnictwa, bądź w inny sposób dostatecznie odróżniający listę od pozostałych zgłoszonych list, celem uniknięcia wprowadzania w błąd wyborców. Ewentualny spór między stronnictwami w tym zakresie miał być rozwiązywany przed przewodniczącym okręgowej komisji wyborczej, najpierw przez wezwanie pełnomocników list do zawarcia porozumienia, a w razie braku konsensusu w tym zakresie, po uprzednim przeprowadzeniu postępowania mającego na celu dowiedzenie przez strony sporu powiązań z danym stronnictwem. W przypadku braku dostatecznego wykazania powiązań z danym ugrupowaniem, przewodniczący okręgowej komisji wyborczej pozostawiał takie listy bez oznaczenia (art. 49). Istotną zmianę w zakresie trybu zgłaszania kandydatów, stanowił przyjęty w art. 52, obowiązek potwierdzenia przyjętego zgłoszenia listy kandydatów wraz z oświadczeniami kandydatów o wyrażeniu zgody na kandydowanie, a także zgłoszenia przyłączenia się listy okręgowej do listy państwowej, jeśli takie miało miejsce, przez przewodniczącego okręgowej komisji wyborczej. Przewodniczący badał również, czy dokonane zgłoszenia zostały poczynione zgodnie z przepisami ustawy. W razie stwierdzenia uchybień w tym zakresie, powiadamiał pełnomocnika listy w terminie do 3 dni od dnia przyjęcia zgłoszenia (art. 53). Pełnomocnik zaś zobligowany był do usunięcia tych braków lub wad w terminie 5 dni od dnia przyjęcia zgłoszenia, pod warunkiem stwierdzenia nieważności zgłoszonej listy w całości lub w odniesieniu do poszczególnych kandydatur. Przewodniczący okręgowej komisji wyborczej o decyzji podjętej w tym zakresie zawiadamiał pełnomocnika listy (art. 54).

Zgodnie z treścią przepisu art. 55, w sytuacji zgłoszenia w okręgu wyborczym $\mathrm{w}$ terminach, o których mowa $\mathrm{w}$ art. 44, list z ogólną liczbą kandydatów nie przewyższającą liczby mandatów w danym okręgu wyborczym, bądź też zgłoszenia jednej wyłącznie listy, głosowania wówczas nie przeprowadzano. W pierwszym przypadku za wybranych uważało się wszystkich zgłoszonych kandydatów, zaś mandaty nie obsadzone przypisywano listom państwowym. W drugim przypadku wybranymi były osoby na tylu pierwszych miejscach listy, ilu posłów miało być wybranych $\mathrm{w}$ danym okręgu, z zastrzeżeniem przepisu art. 97 ust. 2 i 3. W sytuacji zgłoszenia kilku list o łącznej liczbie kandydatów przewyższającej liczbę mandatów w danym okręgu wyborczym, okręgowa komisja wyborcza, po końcowym ustaleniu list, zarządzała wydrukowanie ich na afiszach wyborczych pod nazwami i numerami, jakie im przysługiwały, z uwzględnieniem kolejności ich numerów. Taki stan rzeczy wynikał $\mathrm{z}$ faktu, iż w wyborach można było 
głosować wyłącznie na numery list [Kacperski 2007: 211]. Afisze wyborcze rozsyłane były, z poleceniem ich rozpowszechnienia, najpóźniej na 12 dni przed wyborami do obwodowych komisji wyborczych. Afisz taki należało przesłać także do Głównego Urzędu Statystycznego.

Na podstawie przepisu art. 57 pełnomocnik okręgowej listy kandydatów mógł złożyć na ręce przewodniczącego okręgowej komisji wyborczej pisemne oświadczenie (nie później niż 22 dni przed dniem wyborów), że listę, którą reprezentuje, przyłącza do oznaczonej w tym oświadczeniu listy państwowej, pod warunkiem, iż lista ta była oznaczona tym samym mianem co lista państwowa. Oświadczenia takie było niezwłocznie przedkładane Generalnemu Komisarzowi Wyborczemu.

Z kolei listy państwowe, zgodnie z postanowieniami art. 58, miały być zgłaszane Generalnemu Komisarzowi Wyborczemu najpóźniej na 40 dni przed dniem wyborów. Zgłoszenie powinno było być opatrzone podpisami co najmniej 5 posłów lub senatorów ustępującej izby parlamentu bądź przez grupę co najmniej 1000 wyborców pochodzących z dwóch okręgów wyborczych, po minimum 500 z każdego z tych okręgów, z wykluczeniem możliwości poparcia więcej niż jednego zgłoszenia. Zdaniem J. Buzka rozwiązanie przyjęte przez ustawodawcę w tym zakresie skutkować będzie możnością zgłoszenia kandydatów właściwie przez większość ugrupowań znajdujących się w sejmie i w konsekwencji będzie próbą zapobieżenia rozdrobnieniu sceny politycznej. Nie powinno to stanowić, w ocenie J. Buzka, większego obciążenia dla kandydatów, bowiem w porównaniu do innych krajów, polski ustawodawca nie wprowadził wymogu uwierzytelniania podpisów poparcia [Buzek 1992: 71]. Ograniczenie ustawowe wprowadzone w ust. 4 polegało na zgłoszeniu na liście państwowej [Peretiakiewicz 1924: 111] ${ }^{13}$ maksymalnie 100 kandydatów [Buzek 1922:72; Paszkudzki 1926: 29: Pietrzak 1989: 119] $]^{14}$. Każda z kandydatur mogła być zgłoszona wyłącznie za jego zgodą, zaś pisemne oświadczenia w tym zakresie należało złożyć na ręce przewodniczącego Państwowej Komisji Wyborczej najpóźniej do 32 dnia przed dniem wyborów. Oświadczenie takie zawierało także potwierdzenie ze strony kandydata, że uważa się on za obywatela polskiego i dysponuje biernym prawem wyborczym. Kandydat mógł być zgłoszony

${ }^{13}$ Jako cel wprowadzenia list państwowych A. Peretiatkowicz podawał ,,podniesienie poziomu umysłowego Sejmu". Wydaje się, iż to był jeden z celów. Jako kolejny można podać obawę przed nieuzyskaniem mandatu przez znaną osobistość, która w wyborach powszechnych w okręgu wyborczym, przy niesprzyjających okolicznościach, włącznie z obowiązującym system wyborczym, mogła mandatu nie uzyskać.

${ }^{14}$ Rozwiązaniu temu J. Buzek przyznaje miano daleko idącej demokratyzacji procesu wyborczego, wskazując przykład Czechosłowacji, gdzie lista okręgowa może zawierać nie więcej niż o 1/3 niż przypisana jest liczba mandatów w tym okręgu. Ordynacja wyborcza do Sejmu i Senatu uchwalona na posiedzeniu Sејтu Ustawodawczego w dniu 28-tym lipca 1922 ze wstepem posta Mieczysława Niedziatkowskiego, Warszawa 1922, s. 28-29. 
wyłącznie na jednej liście państwowej (art. 59 ust. 2). Generalny Komisarz Wyborczy ogłaszał najpóźniej 30 dnia przed dniem wyborów w dzienniku Monitor Polski ważnie zgłoszone państwowe listy kandydatów oznaczone numerami według kolejności ich składania.

Uchwalenie w dniu 28 lipca 1922 roku ustawy ordynacji wyborczej do Senatu ${ }^{15}$ było konsekwencją postanowień art. 2 konstytucji marcowej, w świetle których organem władzy ustawodawczej prócz Sejmu, jest także Senat. W art. 1 ordynacji wyborczej do Senatu z 1922 roku ustawodawca wskazał na konieczność odpowiedniego stosowania przepisów ordynacji sejmowej z 1922 roku, jeżeli postanowienia ordynacji senackiej nie stanowiłyby inaczej. Tryb zgłaszania kandydatów został określony w art. 14 oraz 15 ustawy. Zgłaszający listę państwową w wyborach do sejmu mogli złożyć oświadczenie, że jednocześnie przedkładają zgłaszają listę państwową do Senatu, wnosząc tym samym o tożsame oznaczenie numeryczne obu list. Wniosek ten mógł być pozytywnie rozpatrzony przez komisję wyborczą, jeżeli lista kandydatów do Senatu została zgłoszona w przypisanym terminie.

Na uwagę zasługuje przyjęte przez ustawodawcę rozwiązanie w ust. 2 i 3 art. 14. W przypadku, gdy ta sama grupa wyborców zgłosiła wyłącznie państwową listę do Sejmu, wówczas numer jej przypisany nie może być zastosowany do jakiejkolwiek innej listy państwowej do Senatu. Analogicznie przepisy te znajdowały zastosowanie także przy oznaczaniu numerami wojewódzkich list kandydatów do Senatu, które nie zgłosiły swego akcesu do innej ważnie zgłoszonej państwowej listy kandydatów. W mojej ocenie słuszność postanowień w tym zakresie przejawia się w dbałości ustawodawcy o usystematyzowanie $\mathrm{w}$ możliwie najwyższym stopniu list kandydatów, co $\mathrm{w}$ okresie początkowego funkcjonowania systemu wyborczego jest dla wyborcy niezwykle istotne. Transparentność zasad, reguł rządzących wyborami dla odbiorcy, który w nieodległym okresie czasu korzysta z przysługujących mu praw wyborczych ma fundamentalne znaczenie. Tak przyjęty stan rzeczy niejako wzbudzał i utwierdzał w wyborcy przekonanie, że żadne inne ugrupowanie polityczne, któremu poparcia nie zamierzał udzielić w wyborach do Senatu, nie będzie występowało niejako zamiast stronnictwa, z którym sympatyzował, a które listy kandydatów w wyborach do Senatu nie zgłosiło. Zgodnie z dyspozycją art. 15 liczba kandydatów na liście państwowej nie może przewyższać liczby 25 , natomiast na liście wojewódzkiej dwukrotnej liczby senatorów przydzielonych według liczby mandatów określonych w art. 6 ordynacji do Senatu z 1922 roku.

${ }^{15}$ Dz. U. R. P. nr 66, poz. 591. 


\section{INSTYTUCJA PEŁNOMOCNIKA I MĘŻA ZAUFANIA}

Intencją ustawodawcy dla powołania w ordynacji sejmowej z 1918 roku, ordynacji sejmowej z 1922 roku oraz Ordynacji do Sejmu Ustawodawczego z 1946 roku instytucji pełnomocnika była okoliczność zapewnienia sprawnego procesu komunikacji z organami wyborczymi w odniesieniu do zgłoszonych list kandydatów. W okresie międzywojennym instytucja mężów zaufania [Skotnicki 2018: 85-93] po raz pierwszy pojawiła się w ordynacji wyborczej do sejmu z 1918 roku. Zgodnie z przepisem art. 62 tego aktu prawo obecności w lokalu wyborczym, od chwili rozpoczęcia czynności aż do zakończenia głosowania, posiadali przedstawiciele grup wyborczych, zgłoszeni przez pełnomocników w liczbie jednego do każdej z komisji spośród wyborców zamieszkujących w danym okręgu. Rolę męża zaufania w przepisach ordynacji z 1918 roku deprecjonował J. Siemieński [1919: 57], wskazując, iż ustawową sankcją za „nadużycie zaufania wyborców” jest podleganie przezeń karze ,jak urzędnik na służbie”. Karę tę należy uznać, za J. Siemieńskim, za niezbyt dotkliwą.

Wynikiem niepożądanych czy nieuczciwych działań męża zaufania, który właściwie pełnił rolę dziś nieznaną, niejako doradcy, pełnomocnika, jeśli wyborca był analfabetą, mogło być na szerszą skalę nawet deformowanie wyników wyborów. Na mocy postanowień art. 63 i 65 ordynacji wyborczej do sejmu z 1922 roku $^{16}$ mężowie zaufania (a także ich zastępcy) mogli być zgłoszeni przez pełnomocników spośród wyborców zamieszkujących w danym okręgu, po jednym do każdej z komisji. Komisja wyborcza dysponowała także uprawnieniem wydalenia męża zaufania (zastępcy), po uprzednim złożeniu mu upomnienia, w sytuacji, gdy zakłócał spokój, bądź prowadził agitację. Fakty wydalenia męża zaufania z lokalu wyborczego należało odnotować w protokole sporządzanym przez komisję. Mężowie zaufania posiadali także, na równi z członkami komisji, prawo zakwestionowania tożsamości osoby głosującej. Do ich obowiązków należała kontrola godzin otwarcia lokalu wyborczego, wykluczenia agitacji na terenie lokalu, dokładności w zakresie obliczania głosów oraz spisania protokołu ${ }^{17}$. Przepisy te odpowiednio stosowano w wyborach do senatu.

\section{SWOBODA PROWADZENIA KAMPANII WYBORCZEJ}

Już na początku XX wieku w literaturze wskazywano na konieczność swobodnego prowadzenia szeroko pojętej kampanii wyborczej, opartej na ,nieograniczonej wolności zebrań i związków”, bez konieczności uzyskiwania jakichkol-

\footnotetext{
${ }^{16}$ Bliżej Ordynacja wyborcza do Sejmu i Senatu..., s. 30.

${ }^{17}$ Tamże.
} 
wiek pozwoleń od służb policji, z pełną wolnością druku, z zapewnieniem prawa wstępu na tego rodzaju zgromadzenia wszystkim zainteresowanym, także młodzieży [X 1906: 16-19]. Problematyka agitacji wyborczej poruszona została także przez J. Siemieńskiego, autora jednego z projektów ordynacji wyborczej do sejmu, opracowanego na potrzeby Komisji Konstytucyjnej TRS. Wskazał on, iż obowiązkiem każdego obywatelskiego projektu wyborczego jest posiadanie specyficznych, tylko i wyłącznie jemu przypisanych barw, na których mają być wydawane ,szyldy, plakaty, odezwy i wszelkie pisemne lub obrazowe środki agitacyjne", te zaś podlegałyby zatwierdzeniu przez odpowiedni urząd wyborczy [Siemieński 1919: 13].

Ordynacja wyborcza do sejmu z 1918 roku nie regulowała kwestii prowadzenia kampanii wyborczej. Jedynie z przepisu art. 61 wnioskować należy, iż w dniu głosowania obowiązywała cisza wyborcza, przynajmniej na terenie lokalu wyborczego, podczas której zakazane było prowadzenie agitacji. Jak podaje Czesław Brzoza [1989: 564], kampania miała charakter informacyjny o prawach wyborczych, zmianach w tym zakresie wprowadzonych przepisami ordynacji oraz edukacyjno-motywacyjny. Podkreślano wagę samego aktu głosowania, którego rezultat wpłynąć miał na losy państwa. Wart podkreślenia jest fakt współcześnie znanej formy agitacji wyborczej, door to door, którą Andrzej Czarski [1918: 7] podawał jako stosowaną, prócz akcji uświadamiających i organizowania zebrań, wieców i dyskusji, celem przekazania wyborcom treści programowych.

\section{CISZA WYBORCZA}

W odniesieniu do przepisów ordynacji wyborczej do sejmu z 1922 roku problematyka ta była równie lakonicznie potraktowana przez ustawodawcę. Cisza wyborcza obowiązywała, zgodnie z normą przepisu art. 66, podczas głosowania, na terenie lokalu wyborczego, w budynku, w którym lokal znajdował się, a także w promieniu 100 metrów od tego budynku. W tym czasie i w tym zasięgu terytorialnym niedozwolone było wygłaszanie przemówień, rozdawanie kart do głosowania i prowadzenie agitacji w jakiejkolwiek formie. Wnioskować zatem należy, iż swoista kampania wyborcza mogła być prowadzona od dnia ogłoszenia zarządzenia o wyborach, nawet $\mathrm{w}$ dniu głosowania poza ramami czasowymi i terytorialnymi określonymi w przepisach ustawy.

Ponadto, zgodnie z treścią art. 65 ust. 1, przewodniczący komisji mógł zarządzić usunięcie osób agitujących w lokalu wyborczym z jednoczesnym zakazem powrotu. Kampania wyborcza prowadzona była w sposób bezkompromisowy. Organizowano liczne spotkania z wyborcami i wiece przedwyborcze, ale główny bój toczył się na łamach prasy [Kamińska-Szmaj 1994: 11]. Ta forma przekazu była podczas agitacji wyborczej niezwykle popularna i powszechnie dostępna, 
bowiem w tym czasie na ziemiach polskich ukazywało się od 1000 do 1100 czasopism [Kamińska-Szmaj 1994: 14]. Wart podkreślenia jest fakt, iż w dniu 5 sierpnia 1922 roku została uchwalona ustawa w sprawie wolności zgromadzeń przedwyborczych $^{18}$, zgodnie z treścią której, wszelkie zgromadzenia wyborcze wymagały zezwolenia władz administracyjnych, bądź co najmniej zgłoszenia stosownym władzom. Za cel takiej regulacji w ówczesnych realiach przyjmuj się zapewnienie porządku i bezpieczeństwa obywatelom, którzy mogą wcale nie wyrażać woli udziału w tego rodzaju zgromadzeniach, ale jeśli odbywają się w wolnej przestrzeni, to siłą rzeczy, poruszając się po drodze w pobliżu, mogą stać się ich biernymi uczestnikami.

\section{MOŻLIWOŚĆ WERYFIKACJI WYBORÓW}

$\mathrm{Na}$ gruncie prawa polskiego problematyka weryfikacji wyborów poddawana była ewolucji. Rozwiązania przyjęte w okresie pierwszej dekady dwudziestolecia międzywojennego oparte były o tzw. system mieszany. Istotę tego systemu stanowiło przyjęcie założenia o podziale mandatów na oprotestowane, czyli takie, wobec których wyborca wniósł protest wyborczy, oraz na mandaty nieoprotestowane [Buczkowski 1998: 109]. Projekt sejmowej ordynacji wyborczej sporządzony przez J. Buzka, stanowiący podstawę prac Komisji Konstytucyjnej TRS, zakładał, iż ważność wyborów, o ile nie podlegały oprotestowaniu, rozpatrywać miała sama Izba Poselska. Z kolei wybór oprotestowany podlegał badaniu przez Trybunał Wyborczy [Buzek 1918: 19] ${ }^{19}$. Mandat wybranego posła uważano za nieważny w przypadku, gdy poseł nie miał biernego prawa wyborczego, bądź je utracił, albo też ,dopuścił się przy wyborze przekupstwa, wymuszenia lub oszustwa" [Buzek 1918: 19]. Pozytywne rozpatrzenie protestu wyborczego skutkowało zastosowaniem instytucji wejście kolejnego kandydata $\mathrm{z}$ listy.

Projekt J. Buzka zakładał także okoliczność unieważnienia całych wyborów, jeżeli zostanie stwierdzone, że:

1) w danym okręgu dokona się ,przekupstw, wymuszeń lub innych podejść oszukańczych, zdolnych zmienić wynik wyborów"

bądź

2) jeżeli w toku postępowania wyborczego nie stosowano przepisów ordynacji wyborczej w stopniu mającym wpływ na wynik wyborów.

Konsekwencją takich ustaleń było zarządzenie w terminie 15 dni od dnia wydania orzeczenia wyborów uzupełniających w tym zakresie [Buzek 1918: 19].

${ }^{18}$ Dz. U. R. P. nr 66, poz. 594.

${ }^{19}$ W skład Trybunału Wyborczego wchodziło trzech członków najwyższego sądu administracyjnego wybranych na posiedzeniu plenarnym oraz czterech członków Trybunału Kompetencyjnego. 
W terminie 14 dni od dnia ogłoszenia wyników wyborów przez główną komisję wyborczą, każdy obywatel - wyborca, zgodnie z art. 88 ordynacji sejmowej z 1918 roku, mógł wnieść protest, w dwóch egzemplarzach, przeciwko wyborowi na ręce przewodniczącego komisji. Przewodniczący komisji ogłaszał niezwłocznie w dzienniku urzędowym państwa oraz w dzienniku miejscowym informację o zaistnieniu takiego faktu, wyznaczając 10-dniowy termin na wniesienie zarzutów przeciwko protestowi. Prawo wglądu do wyłożonego w tym okresie protestu przysługiwało każdemu wyborcy. Jeden egzemplarz protestu wyborczego przesyłany był do Sądu Najwyższego w Warszawie lub Krajowego Sądu Wyższego w Krakowie, które działały na zasadach Trybunału Wyborczego. O ważności wyborów zaprotestowanych w tym trybie sądy te orzekały w składzie trzech sędziów w terminie sześciu miesięcy od dnia wyboru (art. 90) [Bogucki 1918: 21-22].

Natomiast ważność wyborów nieoprotestowanych rozstrzygał sejm w ciągu dwóch miesięcy od dnia wyboru. W sytuacji, gdy nie wpłynął żaden protest w odniesieniu do wyboru posła, a wybór jego był kwestionowany, wówczas sejm oddawał sprawę do zbadania i rozstrzygnięcia Sądowi Najwyższemu (art. 96). W przypadku zaistnienia okoliczności unieważnienia mandatu posła, stosowano metodę wejścia kandydata $\mathrm{z}$ listy, który otrzymał kolejny wynik. Zasada ta nie mogła być zastosowana, jeżeli w danym okręgu wyborczym „mandat poselski został uzyskany przy użyciu przekupstw wymuszeń, fałszu lub jakichkolwiek podejść" bądź jeżeli w toku postępowania wyborczego nie stosowano przepisów ordynacji wyborczej [Bogucki 1918: 21]. W terminie 15 dni od dnia wydania orzeczenia sądu o niemożności wskazania kolejnego kandydata z listy, Ministerstwo Spraw Wewnętrznych zarządzało przeprowadzenie wyborów w danym okręgu wyborczym lub obwodzie głosowania [Bogucki 1918: 23].

Z kolei ustawodawca w art. 102 ordynacji sejmowej z 1922 roku ustanowił możliwość wniesienia protestu także przeciwko wyborom, co można było uczynić $\mathrm{w}$ formie pisemnej lub ustnej do protokołu na ręce przewodniczącego okręgowej komisji wyborczej. Natomiast wniesienie protestu przeciwko wyborowi posła z listy państwowej lub przeciwko wynikom wyborów ustalonym przez Komisję Państwową zostać złożone na ręce Generalnego Komisarza Wyborczego.

W kolejnym etapie organ, na którego ręce protest został złożony, ogłaszał ten fakt w Monitorze Polskim oraz w dziennikach miejscowych, wyznaczając tym samym 14-dniowy termin na wniesienie zarzutów przeciwko treści w nim zawartej. Oprócz możności przeglądania w tym czasie protestu, ustawodawca przyznał także prawo wykonywania jego odpisów (art. 103 ust. 2). Po upływie tego terminu, protest wraz z wniesionymi zarzutami przesyłany był do Sądu Najwyższego, zaś jego odpis do Biura Sejmowego. Z kolei nieoprotestowane mandaty mogły podlegać weryfikacji z punktu widzenia posiadanego prawa wyborczego przez mandatariusza $\mathrm{w}$ ciągu trzech pierwszych posiedzeń $\mathrm{w}$ trybie przypisanym dla wniosków poselskich, zaś w przypadku jego zakwestionowania Sejm 
przekazywał uchwałą sprawę do zbadania i rozstrzygnięcia Sądowi Najwyższemu (art. 104 ust. 1 i 3). Znaczenie zastosowania instytucji orzekania o ważności wyborów oprotestowanych przez niezawisłe sądy podkreślał Antoni Peretiatkowicz [1924: 113], co - jego zdaniem - wyróżniało państwo polskie na tle tych państw, w których system demokratyczny obowiązuje od dawna.

\section{KONKLUZJA}

Wprowadzone i co do zasady z powodzeniem funkcjonujące w praktyce wyborczej dwudziestolecia międzywojennego instytucje prawa gwarantujące realizację swobód wynikających z zasady wolnych wyborów stanowią fundament dla współczesnych instytucji prawa wyborczego. Analiza zarówno przedkładanych w toku, jak i podejmowanych prac legislacyjnych u progu odradzania państwa polskiego instytucji gwarantujących realizację zasady wolnych wyborów dowodzi tego, iż twórcy ówczesnych instytucji prawa, będących pionierskimi na ów czas, daje asumpt do stwierdzenia, że zasada wolnych wyborów była i jest praktykowana w polskim systemie prawa od ponad 100 lat.

\section{BIBLIOGRAFIA}

Ajnenkiej Andrzej. 1991. Polskie konstytucje. Warszawa: WSiP.

Antoszewski Andrzej. 2006. Systemy wyborcze. W Systemy polityczne wspótczesnej Europy. Red. Andrzej Antoszewski, Ryszard Herbut. Warszawa: Wydawnictwo Naukowe PWN.

Banaszak Bogusław. 1993. „Opinia o ustawie uchwalonej dnia 15 kwietnia 1993 r. Ordynacja wyborcza do Sejmu RP (druk senacki nr 179)". Zeszyty Biura Studiów i Analiz Kancelarii Senatu 140.

Banaszak Bogusław. 2008. Prawo konstytucyjne. Warszawa: Wydawnictwo C.H. Beck.

Bogucki Antoni. 1918. Ordynacja wyborcza do Sejmu Ustawodawczego. Warszawa: WSiP.

Bożyk Stanisław. 2006. Partie polityczne a Sejm RP. Warszawa: Wydawnictwo Sejmowe.

Brzoza Czesław. 1989. „Wybory do Konstytuanty w Krakowie w 1919 roku w świetle współczesnej prasy". Studia Historyczne 4.

Buczkowski Jerzy. 1998. Podstawowe zasady prawa wyborczego III Rzeczypospolitej. Lublin: Wydawnictwo UMCS.

Buzek Józef. 1918. Projekt konstytucji państwa polskiego i ordynacji wyborczej sejmowej oraz uzasadnienie i porównanie projektu konstytucji państwa polskiego z innymi konstytucjami. Wstęp ks. H. Przeździecki, t. I-IV [b.m.w.].

Buzek Józef. 1922. Gtówne zasady polityczne ordynacji wyborczej do Sejmu i Senatu. Studjum krytyczno-porównawcze. Warszawa-Lwów: Książnica Polska Tow. Nauczycieli Szkół Wyższych.

Chmaj Marek. 2008. Zasady polskiego prawa wyborczego. W System wyborczy w Rzeczypospolitej Polskiej. Red. Marek Chmaj, Wiesław Skrzydło. Warszawa: Wydawnictwo Wolters Kluwer. 
Chmaj Marek, Żmigrodzki Marek. 1995. Status prawny partii politycznych w Polsce. Toruń: Wydawnictwo Adam Marszałek.

Czarski Antoni. 1918. Jak i kogo wybierać do Sejmu. Warszawa.

Galster Jan. 2002. Kilka uwag o aksjologii prawa wyborczego. W Prawo wyborcze Rzeczypospolitej Polskiej i problemy akcesji do Unii Europejskiej. Materiały XLIV Ogólnopolskiej Konferencji Katedr i Zakładów Prawa Konstytucyjnego. Olsztyn 25-27 kwietnia 2002 roku. Red. Andrzej Sylwestrzak. Olsztyn: Wydawnictwo UWM.

Garlicki Leszek. 2010. Polskie prawo konstytucyjne. Zarys wyktadu. Warszawa: Wydawnictwo Liber.

Gebethner Stanisław. 1989. „Wybory do Sejmu i Senatu 1989 r. (wstępne refleksje)”. Państwo i Prawo. 8.

Grabowska Mirosława, Szawiel Tadeusz. 2003. Wstęp. Demokracja-partie polityczne - społeczeństwo. W Budowanie demokracji. Podziały społeczne, partie polityczne i społeczeństwo obywatelskie w postkomunistycznej Polsce. Red. Mirosława Grabowska, Tadeusz Szawiel. Warszawa: Wydawnictwo Naukowe PWN.

Ilski Zdzisław. 2013. Formuła wyborcza u progu niepodległej Polski (do 1922 r.). Toruń: Wydawnictwo Adam Marszałek.

Jodko-Narkiewicz Witold. 1918. Jaka powinna być ordynacja wyborcza do przyszłego Sejmu Polskiego. Warszawa: S. Orgelbrand i Synowie.

Kacperski Kamil. 2007. System wyborczy do Sejmu i Senatu u progu Drugiej Rzeczypospolitej. Warszawa: Wydawnictwo Sejmowe.

Kamińska-Szmaj Irena. 1994. Judzi, ohydza, ze czci ociera. Język propagandy politycznej w prasie 1919-1923. Wrocław: Towarzystwo Przyjaciół Polonistyki Wrocławskiej.

Komarnicki Wacław. 1922. Polskie prawo polityczne (geneza i system). Warszawa: Księgarnia F. Hoesicka.

Komarnicki Wacław. 1932. Ordynacje wyborcze do Sejmu i Senatu z dnia 28 lipca 1922 roku w świetle uwag prawniczych. Warszawa: Księgarnia F. Hoesicka.

Kryszeń Grzegorz. 2008. Prawo wyborcze do parlamentu. Status prawny postów i senatorów. W Prawo konstytucyjne. Red. Marian Grzybowski. Białystok: Wydawnictwo Temida 2.

Momro Paweł. 2013. Parlament w Polsce. Przemiany polityczno-ustrojowe na przestrzeni XX wieku. Kraków: Paweł Momro.

Ochimowski Feliks. 1906. Prawa konstytucyjne. Szkic porównawczy. Warszawa: Druk. Piotra Laskauera i S-ki.

Paszkudzki August. 1926. Konstytucja Rzeczypospolitej Polskiej z dnia 17 marca 1921 roku. Komentarz. Lwów-Warszawa: Książnica-Atlas.

Peretiatkowicz Antoni. 1924. Państwo wspótczesne. Poznań: Fiszer i Majewski.

Pietrzak Michał. 1989. „Państwo prawne w konstytucji z 17 marca 1921 r.”. Czasopismo Prawno-Historyczne 2.

Siemieński Józef. 1918. Projekt Konstytucji Państwa Polskiego i ordynacji wyborczej sejmowej. Wnioski zasadnicze do projektu Konstytucji i ordynacji wyborczej złożone w Komisji Sejmowo-Konstytucyjnej Tymczasowej Rady Stanu. Warszawa: Drukarnia Państwowa Królestwa Polskiego. Odbitka z wydawnictwa rządowego.

Siemieński Józef. 1919. Rozbiór krytyczny ordynacji wyborczej do Sejmu Ustawodawczego. Warszawa: Księgarnia F. Hoesicka.

Skotnicki Krzysztof. 2018. „Instytucja mężów zaufania w polskim prawie wyborczym w okresie międzywojennym". Studia Wyborcze 25.

X. 1906. Jakim powinno być prawdziwe przedstawicielstwo ludowe? Ze wsteppem A. Warskiego. Warszawa: Biblioteka Naukowa.

Żukowski Arkadiusz. 2004. System wyborczy do Sejmu i Senatu RP. Warszawa: Wydawnictwo Sejmowe. 


\section{Streszczenie}

Zasada wolnych wyborów stanowi podstawę funkcjonowania współczesnych systemów wyborczych oraz przeprowadzanych elekcji. Wolności determinujące dziś realizację zasady wolnych wyborów, tj. wyłaniania i zgłaszania kandydatów (list kandydatów), prowadzenia kampanii wyborczej oraz swobody preferencji wyborczych przy zapewnieniu jednoczesnego przestrzegania dyrektywy uczciwego procesu wyborczego mają swoją genezę w instytucjach wprowadzonych i praktykowanych tuż po odrodzeniu państwa polskiego.

Słowa kluczowe: zasada wolnych wyborów, wybory w XX-leciu międzywojennym.

\section{ON GUARANTEES FOR THE EXERCISE OF THE FREEDOMS DERIVING FROM THE PRINCIPLE OF FREE ELECTIONS IN THE LEGAL SYSTEM AT THE THRESHOLD OF THE INTERWAR PERIOD (summary)}

On the guarantees of realization of freedoms resulting from the principle of free elections in the legal system at the threshold of the 20th interwar period. The principle of free elections is the basis for the functioning of contemporary electoral systems and elections held. The freedoms that nowadays determine the implementation of the principle of free elections, i.e. selecting and nominating candidates (lists of candidates), conducting an election campaign, and the freedom of electoral preferences while ensuring compliance with the directive of a fair election process, have their origins in institutions introduced and practiced shortly after the rebirth of the Polish state.

Keywords: principle of free elections, elections in the 20th interwar period. 